Zagazig Veterinary Journal

Volume 44, Number 2, p. 106-118, September, 2016

CFaculty of Veterinary Medicine, Zagazig University, 44511, Egypt

DOI: 10.21608/zvjz.2016.7853

\title{
Hematological, Biochemical and Histopathological Changes on Exposure to Aluminum Dust
}

\author{
El- Sayed A. El- Sayed ${ }^{1}$, Maie I. El-Gammal ${ }^{2}$, Samir A. Nassar ${ }^{1}$ and Safaa E. Nassar ${ }^{1}$ \\ ${ }^{1}$ Zoology Department, Faculty of Science, Zagazig University, Egypt \\ ${ }^{2}$ Environmental Sciences Department, Faculty of Science, Damietta University, Egypt \\ Article History: Received: 24/5/2016 Received in revised form: 16/8/2016 Accepted: 5/9/2016
}

\begin{abstract}
Aluminum $(\mathrm{Al})$ is considered the most widely distributed element in nature especially in the earth's crust. Workers in the secondary $\mathrm{Al}$ industries are occupationally exposed to intense environmental $\mathrm{Al}$ dust. This study was carried out to assess the levels of indoor respirable $\mathrm{Al}$ dust in addition to the changes in some hematological and biochemical parameters of the exposed workers. An animal experiment was performed to investigate the histopathological changes on the trachea and lungs of rats exposed to $\mathrm{Al}$ dust to assess the risk of $\mathrm{Al}$ exposure among the workers. The results of this study showed that the highest respirable dust concentration was detected in the finishing department $\left(6459.33 \mu \mathrm{g} / \mathrm{m}^{3}\right)$ that exceeded the permissible exposure limit. While, the lowest concentrations 2182.29 and $1220.88 \mu \mathrm{g} / \mathrm{m}^{3}$ were found in casting and rolling departments, respectively. A significant decrease in RBC's count, $\mathrm{Hb}, \mathrm{HCT}, \mathrm{MCV}, \mathrm{MCHC}$ and platelets number with significant increase in WBC's, lymphocyte counts, serum urea and creatinine level were observed in exposed workers when compared to the control group. Furthermore, rats exposed to inhalation of dust induced some histopathological changes in their trachea and lung tissues. The degree of these changes was proportional to the duration of $\mathrm{Al}$ dust exposure. Thus, strict enforcement of appropriate, effective preventive and control measures must be required.
\end{abstract}

Keywords: Aluminum, respirable dust, risk assessment, hematology.

\section{Introduction}

Aluminum $(\mathrm{Al})$ is an abundant element in the earth's crust [1]. Recovery of Al via recycling has become an important facet of the Al industry. Recycling, until the late 1960s, was a low-profile activity, however, it has been brought to the public awareness since the growing use of $\mathrm{Al}$ beverage cans. Recycling $\mathrm{Al}$ (secondary $\mathrm{Al}$ ) has the same physical properties of primary Al. This process involves melting the scrap which requires only $5 \%$ of the energy used to produce $\mathrm{Al}$ from ore [2]. The respiratory bronchioles and alveolar epithelia are the main target sites for inhaling agents that cause lung injury [3]. Workers in different plants such as miners, smelters and other metal workers are exposed to $\mathrm{Al}$ dusts and aerosols that capable of causing [4].

Manufacturing powder, grinding, finishing, and processing produce Aluminum particles in the form of dust, powder or flake which may be suspended in air resulting in serious damage due to ignition [5]. The deposition of inhaled $\mathrm{Al}$ and its compounds in lungs are based on their particle size [6]. Trapping in the nasopharyngeal and upper respiratory tract of a portion of these particles and then deposition in the gastrointestinal tract through mucosal movement and mucocilliary action occurs. The other portion (smallest particles) reaches the alveoli and can be transferred to blood. About $3 \%$ of $\mathrm{Al}$ has been estimated to be absorbed into the blood from the lung [7].

Elevated industrial and medical $\mathrm{Al}$ exposure may significantly raise its absorption which leads to chronic toxicant to the respiratory system (Shaver's Disease) and the central nervous system (Alzheimer's disease) [8]. It was recently found that $\mathrm{Al}$ provoked nephrotoxicity, cardiotoxicity, hepatotoxicity and hematotoxicity [9-11]. 
There are a few data published from animal long-term studies of biological effects of exposure to different forms of Aluminum, therefore this study was done to evaluate the risk assessment that might generate from secondary Al industry on some hematological and biochemical parameters of the exposed workers. The histopathological changes of $\mathrm{Al}$ dust exposure on the trachea and lung tissue of albino rats was also investigated at different time intervals post exposure.

\section{Material and Methods}

\section{Environmental measurements}

\section{Aluminum Dust Sampling Sites}

This study was conducted at Mit-Ghamr city, Dakahlia, Egypt. It is a center producing $\mathrm{Al}$ accounting for more than $78 \%$ of Egypt's total production, especially $\mathrm{Al}$ utensils. A total of 30 foundries and about 120 forming workshops were scattered within the city. There are about 60 employees per foundry and about 20 employees in each forming workshop. Thus, there are an estimated 1200 employees at these foundries, while the forming workshops employ about 2400 employees; with lack of workplace dust control, ventilation and personal protection. Dust sampling was collected from three departments in the secondary $\mathrm{Al}$ plant (casting, rolling and finishing). All these departments provided with natural ventilation that varies from five to eighteen openings. Workers in all departments have never worn respirators.

\section{Exposure to Aluminum dust concentration}

A total of 216 personal respirable $\mathrm{Al}$ dust samples were collected during 12 consecutive weeks, 2 personal respirable Al-dust samples were measured from each department for three different days per week. Samples were collected for $8 \mathrm{~h}$ on cellulose membrane filters with $0.45 \mu \mathrm{m}$ and $25 \mu \mathrm{mm}$ pore size and diameter, respectively which supported with cassettes and were weighed to an accuracy of $10^{-4}$ using an electro-balance, within the cassettes before and after sampling. The filter efficiency is about $100 \%$ for particles of 0.1 $\mu \mathrm{m}[12]$.

\section{Population Study}

The exposed group included 51 exposed male workers with age ranged from 11 to 62 years old worked at the different departments of the plant for 8 hours/day. All workers gave informed consent to donate blood and urine for the survey. Workers were examined during the working shift $(8 \mathrm{~h})$ and those with liver or kidney diseases were excluded from this study. While, the control group included 40 healthy persons, matched for sex and age were selected from persons who did not exposure to $\mathrm{Al}$ dust.

Blood sampling and analysis

Blood samples were collected from both control and exposed groups. Each sample was divided in two tubes, the first containing EDTA for hematological analysis, while the other was free from anticoagulant for separating sera. Sera was stored at $-20^{\circ} \mathrm{c}$ until biochemical. Red blood cells (RBCs), White blood cells (WBCs), Lymphocytes and platelet count, hemoglobin $(\mathrm{Hb})$ concentration, hematocrit (HCT) value, mean corpuscular volume (MCV), mean corpuscular hemoglobin $(\mathrm{MCH})$ and mean corpuscular hemoglobin concentration (MCHC) were measured using the automated hematological analyzer (Celltac $\alpha /$ MEK$6420 \mathrm{~K})$ [13]. The serum urea concentration was measured according to the method of Patton and Crouch [14], while creatinine concentration was measured by using Human kit (WiesbadenGermany) [15].

\section{Experimental animals}

Sixty adult male albino rats weighing 150$200 \mathrm{~g}$ were housed in plastic cages provided with ad libitum food and drinking water. After two weeks of acclimatization, rats were divided into two groups; control group which consisted of ten rats placed away from the Al plant, while the other fifty rats were kept inside the finishing department of the plant and exposed to dust inhalation which served as exposed group. All rats (control and exposed groups) were sacrificed at 7, 15, 30, 60 and 90 days after exposure to dust inhalation in Al plant (10 rats for each time). Trachea and lungs of each rat were collected, cut into small pieces and fixed 
in $10 \%$ neutral buffered formalin solution then dehydrated, cleared and embedded in paraffin wax. Sections were cut at thickness of $3-4 \mu$, and then stained with hematoxylin and eosin (HE) [16].

\section{Statistical analysis}

Data were collected and analyzed using the computer program SPSS ver. 21 (IBM Corp., Chicago, IL, USA). Independent T-test was used to compare between the studied groups. The results were expressed as mean \pm SD.
Differences were considered significant at $\mathrm{P}<$ 0.05 .

\section{Results \\ Evaluation of respirable Al dust sampling}

The mean respirable $\mathrm{Al}$ dust for casting, rolling and finishing departments was 2182.29, 1220.88 and $6459.33 \mu \mathrm{g} / \mathrm{m}^{3}$, respectively. The respirable $\mathrm{Al}$ dust samples ranged from 250 5000, 208.33 - 2916.67 and 2291.67 $12291.67 \mu \mathrm{g} / \mathrm{m}^{3}$ in casting, rolling and finishing departments, respectively (table1).

Table 1: Mean concentrations of personal respirable Al dust at the different Aluminum plant departments in $\mu \mathrm{g} / \mathrm{m}^{3}$ during three months $(\mathrm{n}=216)$

\begin{tabular}{lccc}
\hline Departments & Mean & Maximum & Minimum \\
\hline Casting & 2182.29 & 5000 & 250.00 \\
Rolling & 1220.88 & 2916.67 & 208.33 \\
Finishing & 6459.33 & 12291.67 & 2291.67 \\
\hline
\end{tabular}

\section{Impact of Al dust on the exposed workers}

The mean values of WBC's and lymphocytes count of the exposed workers were significantly higher $\left(7.43 \times 10^{9}\right.$ cell/1 and $51.96 \%$, respectively) than those of control group $\left(6.61 \times 10^{9}\right.$ cell/1 and $36.80 \%$ respectively) (table 2). However, the mean values of RBC's count, Hb level, Hct value, platelets count, MCV, MCHC, serum urea and creatinine concentration of exposed workers $\left(4.32 \times 10^{12} \mathrm{cell} / \mathrm{l}, 11.61 \mathrm{~g} / \mathrm{dl}, 34.84 \%, 188.23\right.$ x $10^{9}$ cell/l, $77.55 \mathrm{fl}, 33.12 \mathrm{~g} / \mathrm{dl}, 46.76 \mathrm{mg} / \mathrm{dl}$ and $1.30 \mathrm{mg} / \mathrm{dl}$, respectively) were significantly lower than those of the control group $\left(4.73 \times 10^{12}\right.$ cell/l, $13.99 \mathrm{~g} / \mathrm{dl} 41.19 \%$, $224.6 \times 10^{9}$ cell/l, $82.67 \mathrm{fl}, 82.67 \mathrm{fl}, 33.65 \mathrm{~g} / \mathrm{dl}$, $38.37 \mathrm{mg} / \mathrm{dl}$ and $1.02 \mathrm{mg} / \mathrm{dl}$, respectively).

Table 2: Hematological and some biochemical parameters of exposed workers to Al dust and control group

\begin{tabular}{|c|c|c|c|c|}
\hline \multirow[t]{2}{*}{ Parameters } & Exposed workers & control group & \multirow[t]{2}{*}{ t. value } & \multirow[t]{2}{*}{ P-value } \\
\hline & Mean \pm SD* & Mean \pm SD & & \\
\hline WBCs (x 109/1) & $7.43 \pm 2.19$ & $6.61 \pm 0.66$ & 2.29 & $<0.05$ \\
\hline Lymphocytes (\%) & $51.96 \pm 10.32$ & $36.80 \pm 3.48$ & 8.89 & $<0.001$ \\
\hline $\operatorname{RBCs}\left(x 10^{12} / 1\right)$ & $4.32 \pm 0.34$ & $4.73 \pm 0.19$ & 6.79 & $<0.001$ \\
\hline $\mathrm{Hb}(\mathrm{g} / \mathrm{dl})$ & $11.61 \pm 1.03$ & $13.99 \pm 0.72$ & 12.38 & $<0.001$ \\
\hline Het $(\%)$ & $34.84 \pm 3.44$ & $41.19 \pm 3.13$ & 9.08 & $<0.001$ \\
\hline MCV (fl) & $77.55 \pm 5.69$ & $82.67 \pm 12.05$ & 2.68 & $<0.01$ \\
\hline $\mathrm{MCHC}(\mathrm{gm} / \mathrm{dl})$ & $33.12 \pm 0.99$ & $33.65 \pm 0.88$ & 2.70 & $<0.01$ \\
\hline Platelets (x $\left.10^{9} / 1\right)$ & $188.23 \pm 55.87$ & $224.6 \pm 17.45$ & 3.96 & $<0.001$ \\
\hline Creatinin (mg/dl & $1.30 \pm 0.26$ & $1.02 \pm 0.09$ & 6.49 & $<0.001$ \\
\hline Urea (mg/dl) & $46.76 \pm 5.68$ & $38.37 \pm 4.28$ & 7.76 & $<0.001$ \\
\hline
\end{tabular}

*SD: Standard deviation. 
Impact of Al dust on experimental animals (exposed rats)

\section{Histopathological changes}

\section{A-Control group}

There was a normal histological architecture of the lung tissue in control rats including the pulmonary bronchioles $(\mathrm{Br})$, peribronchial blood vessels $(\mathrm{Bv})$, alveolar ducts $(\mathrm{AD})$, alveolar sacs (As) and alveoli (A) with thin interalveolar septa (PL.I-1). Also, the architecture of tracheal tissue revealed that the epithelium formed from pseudostratified ciliated columnar epithelial cells in the mucosal layer, the submucosal layer contains few lymphocytes with intact blood vessels. The layer of hyaline cartilage formed of chondrocytic cells surrounded with extracellular matrix (PL.III-9).

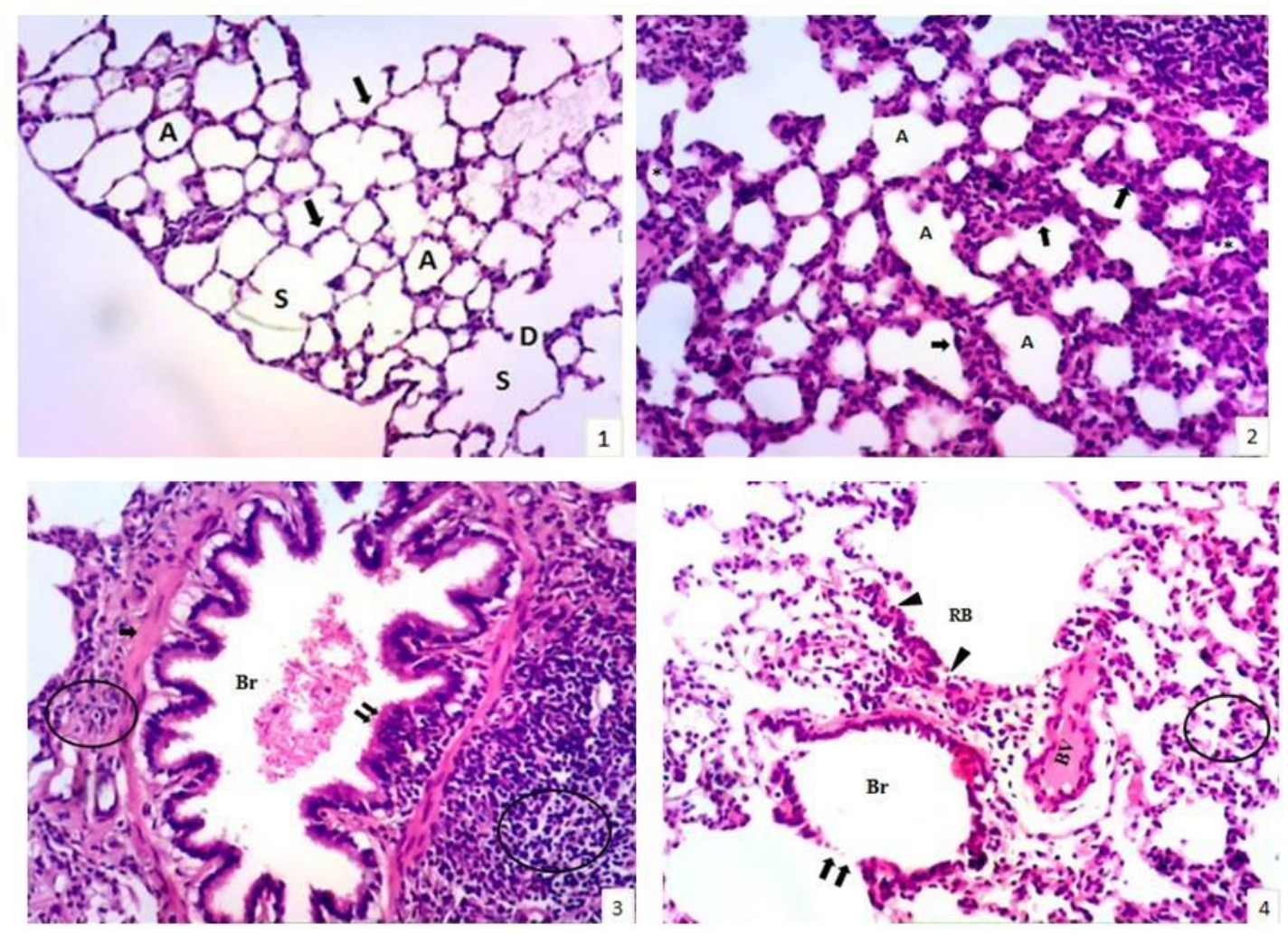

Plate (I): photomicrograph of rat lung in both control and exposed group stained by H\&E. (1: lung of control rat showing alveoli $(\mathrm{A})$ with thin walls (arrows), as well as alveolar ducts (D) and alveolar sacs (S). (X 400). 2: lung after 7 days post exposure to Aluminum dust showing collapsed alveoli $(*)$ others are distended (A), thickened alveolar walls $(\uparrow)$ lymphocytic infiltration inside the lung tissue. (X 400). 3: lung after 7 days post exposure to Aluminum dust indicating a prominent hyperplasia in epithelia $(\uparrow \uparrow)$, the bronchiolar (Br) lumen contains moderate amount of mucin secretion $(M)$, the bronchiolar wall thickened by edematous connective tissue (thick arrow), infiltrated with lymphocytes (circle). (X 400). 4: lung after 15 days post exposure to Aluminum dust showing severely-destructed pulmonary bronchiole (Br) with ruptured epithelial wall ( $\uparrow$ ), congested blood vessels $(\mathrm{Bv})$, another respiratory bronchiole $(\mathrm{RB})$ with destructed epithelia (arrow head), and atelectic alveoli (X 200).

\section{B-Exposed group}

Rats that exposed to Al-dust inhalation were divided into five subgroups: (I): at 7 days post-exposure: Lung tissue showed collapsed alveoli with thickened walls and lymphocytic infiltration (PL.I-2). The epithelia of pulmonary bronchiole revealed a prominent hyperplasia in the form of finger like projections inside the lumen and the bronchial wall appeared thickened by edematous connective tissue beside hyperplastic peribronchiolar lymphoid aggregations (PL.I- 
3). The tracheal tissue revealed several histopathological changes. Disorganization of mucosal epithelia, partial loss of cilia and presence of goblet cells in tracheal epithelia at certain areas with lymphocytic infiltration inside the submucosal layer (PL.III-10).

(II): at 15 days post-exposure: Microscopic examination of the lung tissues revealed severely destructed pulmonary bronchiole with ruptured epithelial wall. Another respiratory bronchiole with destructed epithelial wall and atoletic alveoli beside leukocytic infiltration could be observed (PL.I-4). The tracheal tissue revealed focal necrosis of mucosal epithelia with mild submucosal lymphocytic infiltration (PL.III-11).
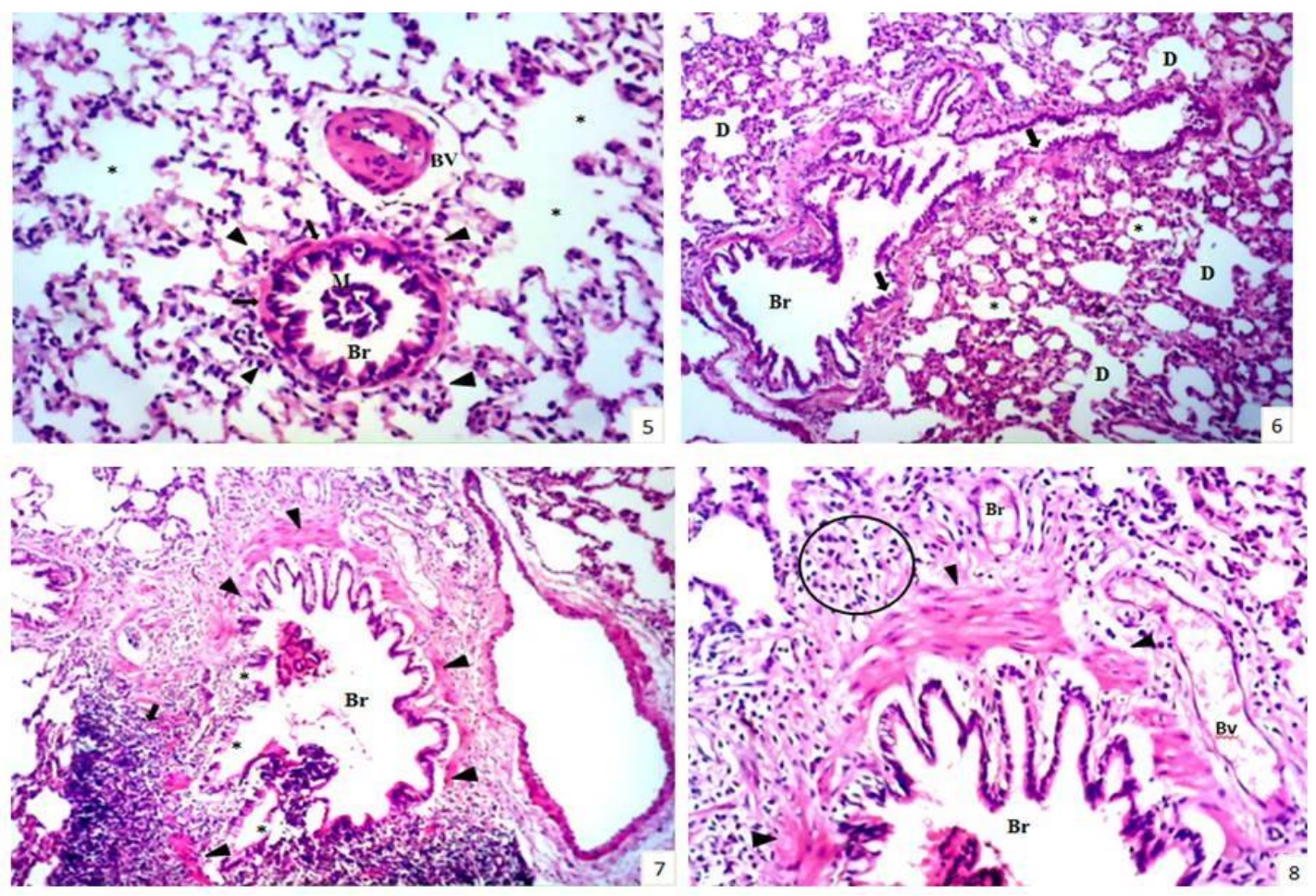

Plate (II): photomicrograph of rat lung in both control and exposed group stained by H\&E. 5: rat lung after 30 days post exposure to Aluminum dust showing a pulmonary bronchiole (Br) with desquamated bronchial epithelia $(\uparrow)$ and mild peri bronchiolar lymphocytic infiltration (arrow heads), hyalinized vascular wall and emphysematous alveoli (*) is markedly recognized. (X 200). 6: lung after 60 days post exposure to Aluminum dust (X 200) showing intense desquamate of hyperplastic bronchiolar epithelia and mild thickening of interalveolar septae $(\uparrow)$. The alveolar tissue appeared with many collapsed alveoli $(*)$ and other with distended nature (D). 7: lung after 90 days post exposure to Aluminum dust showing the bronchial epithelia were destructed (*), bronchiolar wall appeared surrounded by patches of edematous C.T. fibers containing leukocytes (arrow heads). (X 200). 8: A higher magnification for the last photo illustrating marked necrosis of bronchial epithelia (arrow heads), peribronchial and leucocytic infiltration (circle) (X 400 ).

(III): At 30 days post-exposure: Lung tissue showed desquamated epithelia in pulmonary bronchiole with mild peribronchiolar lymphocytic infiltration. The bronchiolar cavity containing deeply stained damaged epithelia. Collapsed blood vessel with hyalinized vascular wall appeared in the field and over swelling of alveoli was markedly recognized (PL.II-5). Concomitant with those histopathological alternations in the lung tissue, the tracheal mucosa also revealed marked epithelial disorganization and partial desquamation beside intensive mononuclear cell infiltration particulary inside the submucosa (PL.III-12).

(IV): At 60 days post-exposure: The pulmonary tissues showed severe changes represented by intense desquamation of hyperplastic bronchiolar epithelium and mild thickening of interalveolar septal by proliferative pneumoctyes (PL.II-6). The tracheal tissue transformation of 
pseudostratified ciliated epithelia into flator cuboidal cells was detected (PL.III-13).

(V): at 90 days post-exposure: The histopathological of the lung tissue appeared much more complicated where the bronchiolar epithelia were severely destructed at some regions. Perivascular, peribronchiolar and interstitial lymphocytic infiltration were

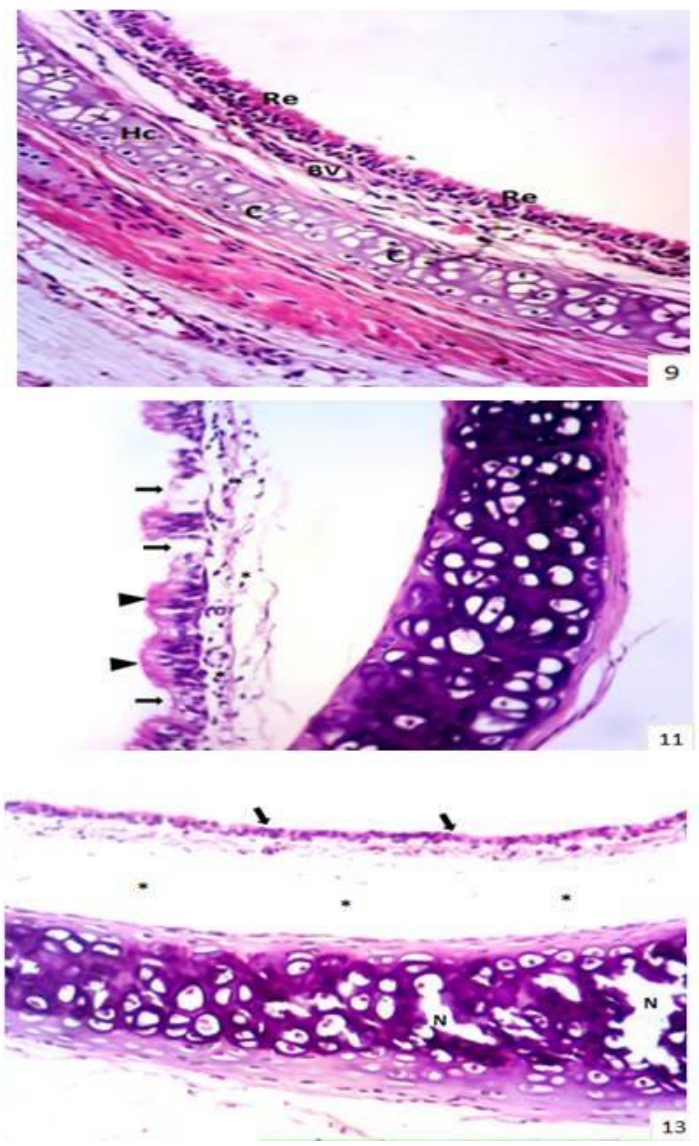

encountered. The bronchial wall appeared surrounded by patches of edematous collagenous C.T. fibers containing leukocytes with hyperplastic peribronchial lymphoid aggregation (PL.II-7,8). The tracheal tissue exhibited transformation of pseudostratified ciliated epithelia into low columnar cells with regional necrosis (PL.III-14).

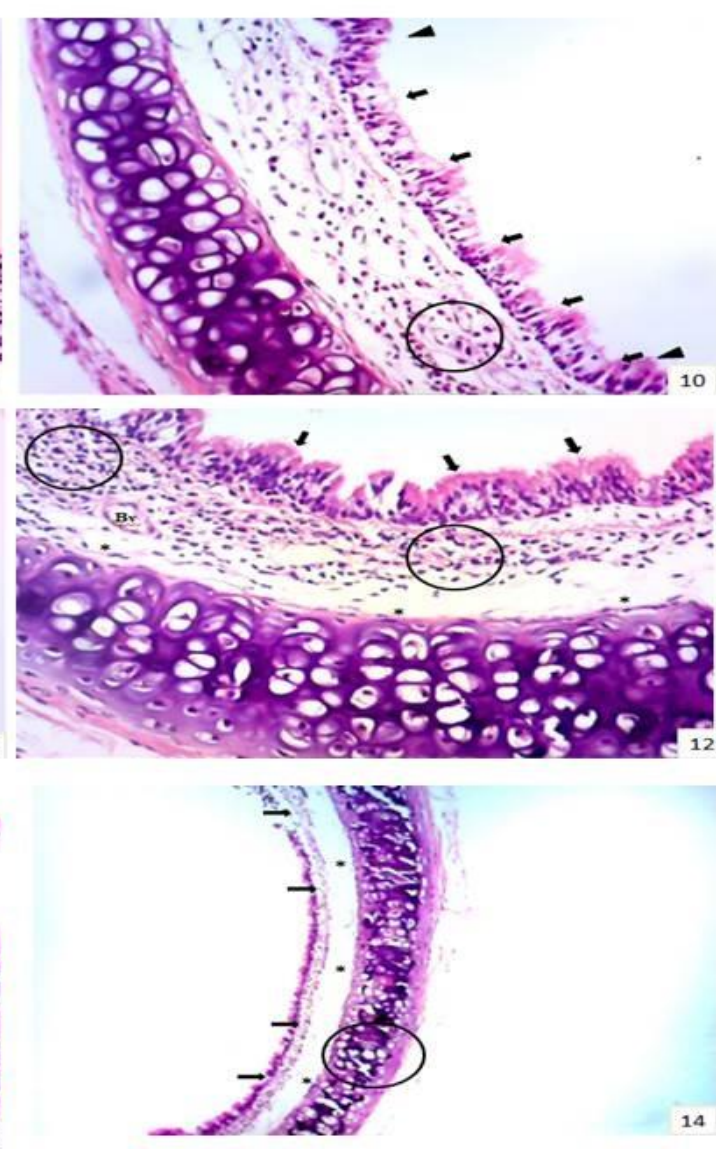

Plate (III): photomicrograph of rat trachea in both control and exposed group stained by H\&E. 9: trachea of control rat showing short pseudostratified ciliated columnar epithelial cells (RE), submucosa containing few lymphocytes and blood vessels (BV), while hyaline cartilage (Hc) layer formed of chondrocytes (C). (X 400). 10: Light micrograph of rat trachea after 7 days post exposure to Aluminum dust showing partial loss of cilia of tracheal epithelial at certain areas $(\uparrow)$., lymphocytic infiltration inside the submucosal layer (circle), mild squamous metaplasia (arrow heads) (X 400). 11: trachea after 15 days post exposure to Aluminum dust showing: focal necrosis of mucosal epith. $(\uparrow)$, increase in the number of epithelial Cells (arrow heads), lymphocytic infiltration (*) (X 400). 12: trachea after 30 days post exposure to Aluminum dust showing; marked epithelial disorganization and partial desquamation $(\uparrow)$. Intensive mononuclear cell infiltration particulary inside the submucosa (circle). Partial loss of the element of the submucosa (*) (X 400). 13: trachea after 60 days post exposure to Aluminum dust shown; epithelial desquamation $(\downarrow)$ and necrosis. Complete loss for the submucosa $(*)$. Necrosis and degeneration in the layer of hyaline cartilage $(\mathrm{N})$. transformation of pseudostratified ciliated epithelia into low columnar cells $(\downarrow)$ (X 400). 14: trachea after 90 days post exposure to Aluminum dust showing; transformation of pseudostratified ciliated epithelia into low columnar cells with regional necrosis $(\downarrow)$, Complete loss for the elements of submucosa $\left({ }^{*}\right)$, intensive vacuolization inside the layer of hyaline cartilage (circle) leading to atrophic degeneration (X 200). 


\section{Discussion}

It was found that differential exposure to respirable $\mathrm{Al}$ dust occurred at all investigated departments. The lowest exposure to respirable $\mathrm{Al}$ dust were measured in casting and rolling departments which were below the threshold limit value (TLV). The National Institute for occupational Safety and Health has established a recommended exposure limit (REL) for Al 5 $\mathrm{mg} / \mathrm{m}^{3}$ for respirable fraction that based on the risk of lung changes that may lead to pulmonary fibrosis [17]. These results were in agreement with those of Godderis et al. [18] who stated that workers of an Al cast-house were exposed to total inhalable fume with a maximum value of $4.37 \mathrm{mg} \mathrm{m}^{3}$ that did not exceed the exposure limits. The mean time weighted average levels respirable dust and $\mathrm{Al}$ metal in a North American smelter were 0.66 and $2.82 \mathrm{mg} / \mathrm{m}^{3}$, respectively [19]. The measured levels were low, compared to the American Conference of Governmental Industrial Hygienists' threshold limit value (TLV) for the specific agent. However, the highest exposures have generally observed in the finishing department during grinding and polishing the surface of utensils. In the current study, it was found that the lowest exposure to respirable $\mathrm{Al}$ dust was found in the casting department, while the highest exposure was found at the finishing department. Nearly similar results were recorded with Kondej and Gawęda [20] who found that differential exposure to total and respirable dust of $\mathrm{Al}$ and its compounds occurred at all investigated workplaces (smelting, founding and mechanical either polishing or grinding). Respirable Al dust concentration at founding and mechanical workplaces was ranged from 0.08- 0.17 and $0.09-0.22 \mathrm{mg} / \mathrm{m}^{3}$, respectively.

The present study showed hematological modifications associated with exposure of workers to Al-dust in secondary $\mathrm{Al}$ industry. The significant increase of WBC's and lymphocyte count in exposed workers may be related to the increased risk of developing respiratory disorders among $\mathrm{Al}$ workers. The release of inflammatory cytokines following pulmonary inflammation, which has an important role in the pathogenesis of atherosclerosis and coronary diseases, is a consequence of inhaled particulates from air pollution leading to systemic changes [21]. The association of elevated ambient particulate levels with the increase in inflammatory markers levels, such as white blood cell count (WBC), has been reported [21,22].

Aluminum may disturb erythropoiesis through combined effects on mature erythrocytes and cellular metabolism in late erythroid progenitors [23]. In addition, Al resembles other xenobiotics in the production of free radicals and reactive oxygen species in cells. Thus, causing release of fatty acid superoxides and oxidation of cellular membrane proteins, resulting in the reduction of cellular membrane fluidity and resulting in damage of the cellular membrane [24]. This reduction may be also resulted from hyperactivity of bone marrow, leading to production of red blood cells with impaired integrity that are easily destroyed in the circulation [25]. Changes in red blood cell counts and hemoglobin levels were accompanied with the decrease in corpuscular volume, corpuscular hemoglobin concentration and platelets count. Such alternations may be associated with some pathological changes developed in blood-forming organs, with the destruction of red blood cells, or both factors together. In accordance, Naylor [26] stated that anemia is resulted from hemodilation, toxic dyshemopiosis and extra- vascular hemolysis.

Regarding kidney indices, increased serum urea and creatinine of $\mathrm{Al}$ exposed workers in the present study were in agreement with Orisakwe et al [27] who stated that the occupational exposure of humans to heavy metals may have long term deleterious effects on liver and renal functions. The elevation in serum urea and creatinine levels in Alexposed workers was considered a significant marker of renal dysfunction. The implication of $\mathrm{Al}$ in the pathogenesis of several clinical disorders, such as renal dysfunction has been previously reported [28]. Because urea is the end-product of protein catabolism, therefore, 
the increased serum urea concentrations of animals treated with $\mathrm{Al}$ may be due to its effect on liver function. Abnormal glomerular function and impaired excretory function of the kidneys were the main cause of elevating creatinine concentration has been interpreted previously [29,30]. Moreover, the promotion of renal failure through $\mathrm{Al}$ accumulation in the kidney and the subsequent systemic toxicity is well known. Renal failure and systemic toxicity are well known due to accumulation of Al. As a consequence, serum urea and creatinine concentration are elevated following renal failure development [31].

Histological examinations of this study revealed that workers exposed to chronic inhalation of the dust in secondary $\mathrm{Al}$ processes showed higher rates of respiratory illness. These respiratory effects were more pronounced in the rat exposed to dust inhalation for 90 days, which may be attributed to the dust concentration and duration of exposure. These findings were in agreement with the published results by Pattajoshi [32] who reported that the concentration of the respirable fraction of airborne dust ( 0.5 to 5.0 micron size) caused lung fibrosis and occupational disorders.

Histological examination of lung tissue of the exposed rats revealed marked gradual increase in lymphocytic infiltration which increased toward the day 90 after exposure. Also, the alveolar tissue appeared with many collapsed alveoli and others emphysematous. These findings were in agreement with the results of previous study performed by Halatek et al. [33] who indicated that $\mathrm{Al}$ foundry dust causes marked irritation and inflammation in the rat lung with focal accumulations of alveolar macrophages within alveolar duct or pleura in some fragments of the lung. Further, interstitial fibrosis, numerous collagen and elastic fibers were observed within the alveoli walls and a significant increase in the thickness of basement membrane was also found. Moreover, lungs of rats exposed to fine particles revealed neutrophil infiltration in the walls and spaces of the alveoli [34].
Inhalation and accumulation of $\mathrm{Al}$ dust and $\mathrm{Al}$ oxide fumes can cause pneumoconiosis and aluminosis [35]. In the present work, the examined sections of lungs revealed an increase in lymphoid tissue accumulation around the bronchioles. A granulomatous illdefined area has been appeared with increasing the duration of exposure. These results were in agreement with the findings reported by Jederlinic et al. [36] who mentioned that workers involved in $\mathrm{Al}_{2} \mathrm{O}_{3}$ abrasives, $\mathrm{Al}$ alloys, and ores production may develop pulmonary fibrosis. Moreover, exposure to excessive dust concentrations produced sustained pulmonary inflammation, enhanced proliferation of pulmonary cells, impairment of particle clearance, deficits in macrophage function, and aggregation of macrophage at the sites of particle deposition and development of pulmonary lesions [37]. Agency for Toxic Substances and Disease Registry (ATSDR) [38] reported that inhaled Al may contribute to the development of pulmonary fibrosis and to a lesser degree pulmonary granulomatosis. Also occupational exposure to Al- dust was associated with pneumoconiosis, interstitial fibrosis and granulomatous lung disease [39].

Concerning the alveolar septae, there was accumulation of macrophage and lymphocyte, that caused thickened of the intra- alveolar septae with a reduction of the alveolar space reduced and irregularly organized alveoli. This was concomitant with the results obtained by Nikula et al. [40] who recorded increased in the thickness of lung interstitial septae which attributed to accumulation of macrophages, giant cells, lymphocytes and plasma cells that causing micro-granulomas in the lung of mice. Also, our results were partially agreed with Ohtsukaa et al. [41] who found that after $\mathrm{Al}$ $(\mathrm{OH})_{3}$ inhalation, infiltration of eosinophils and macrophages were observed around the vessels and bronchi, resulting in mild thickening of interalveolar. Additionally, after exposure to smoke incense; fibrosis of peribronchial, thickening in alveolar walls and aggregation of lymphoid cells were observed in some lung sections [42]. The presences of 
goblet cell metaplasia, desqumation inside the cavity of bronchioles of the exposed rats were detected in the current study. These observations were in agreement with the studies of Alarifi [43] who noticed that some of the bronchi contained the debris and the remnants of the cells falling after exposure to incense smoke.

The examined sections in the present study after 90 days of exposure also showed regional degeneration and necrosis of the bronchial epithelia as well as per bronchial with presence of degenerated leukocytes. These findings were in partial agreement with the results obtained by Dai et al. [44] who found that mineral dust can induce airway wall fibrosis through direct up regulating proliferable and tibrogenic mediators as well as by matrix components in the airway epithelium and interstitium. The presence of tracheitis, bronchitis, peribronchial vascular congestion, peribronchial edema, and atelectasis confirmed the pulmonary injury that occurred after smoke inhalation [45]. In addition, focal necrosis and degradation were detected in some cells of epithelial bronchioles [46].

The histological status of rats' tracheal tissue after 90 days from exposure to $\mathrm{Al}$ dust included; marked epithelial disorganization with loss of cilia at certain areas, goblet cell metaplasia, desquamation and necrosis of mucosal epithelia. Proliferation in submucosal layer with markedly increase in lymphocytic infiltration with the duration of exposure were also observed. Nearly similar results were obtained by Ohtsukaa et al. [41] who observed degeneration, stratification and/or desquamation of mucous epithelial cells in the trachea of rats following $\mathrm{Al}(\mathrm{OH})_{3}$ inhalation. However, histopathological changes such as: subepithelial lymphocytic infiltration, dysplastic changes, hyperchromasis of nuclei, epithelial disorganization and cilia disappearance of rat tracheal epithelium have been resulted from the exposure to formaldehyde vapor with direct relationship with the duration of exposure [47]. The gradual accumulation and long-term retention of Al within the respiratory tract of individuals repeatedly exposed in occupational settings have recently been approved [48]. Furthermore, long- term occupational exposure to dust fumes of $\mathrm{Al}$ and its compounds leads to pulmonary fibrosis, pulmonary alveolitis and alveolar proteinosis, asthma and chronic bronchitis [39].

\section{Conclusion}

From the current study, we can conclude that the Aluminum workers were always at risk to hematological and biochemical disorders and respiratory problems. Therefore, strict enforcement must be set to reduce dust emissions and to protect the workers.

\section{Conflict of interest}

None of the authors have any conflict of interest to declare.

\section{Acknowledgment}

The authors are grateful to the owner of the Al plant for his support.

\section{References}

[1] World Health Organization, WHO (2009): Chemical Hazards in Drinking WaterAluminum (Online) last accessed 02.09.09athttp://www.who.int/water_sanitat ion_health/dwq/chemicals/Aluminumsum.p df.

[2] Hoyle, G. (1995): Recycling opportunities in the UK for Aluminum bodied motor cars. Resources, Conservation and Recycling, 15(3): 181-91.

[3] Tomling, G.; Blaschke, E. and Eklund, A. (1993): Long term effects of alumina on components of bronchoalveotar lavage fluid from rats. Br J Ind Med, 50(2):172-175.

[4] Gitelman, H.J.; Alderman, F.R.; KursLasky, M. and Rockette, H.E. (1995): Serum and urinary Aluminumlevels of workers in the Aluminumindustry. Ann Occup Hyg,39(2):181-191.

[5] Shraideh, A.Z and Najjar, N.H. (2011): Histological changes in tissues of trachea and lung alveoli of albino rats exposed to 
the smoke of two types of narghile tobacco products. Jordan J Biol Sci, 4 (4): 219:224.

[6] ICRP (1994): Human respiratory tract model for radiological protection, ICRP publication 66. Oxford: Pergamon Press, 1-120.

[7] Jones, K. C. and Benett, B. G. (1986): Exposure of man to environmental Aluminum-an exposure commitment assessment. Sci Total Environ, 52(1):6582.

[8] Nieboer, E.; Gibson, B.L.; Oxman, A.D. and Kramer, J.R. (1995): Health effects of Aluminum: a critical review with emphasis on Aluminum in drinking water. Environ Rev; 3(1):29-81.

[9] Kutlubay, R.; Oğuz, E.O.; Güven, C.; Can, B.; Sinik, Z. and Tuncay, O.L. (2007): Histological and ultrastructural evidence for protective effects on Aluminuminduced kidney damage by intraperitoneal administration of $\alpha$-tocopherol. Int $\mathbf{J}$ Toxicol, 26(2):95-101.

[10] Bombi, G.G.; Corain, B.; Favarato, M.; Giordano, R.; Nicolini, M.; Perazzolo, M.; Tapparo, A. and Zatta, P. (1990): Experimental Aluminum pathology in rabbits: effects of hydrophilic and lipophilic compounds. Environ Health Perspect, 89: 217-223.

[11] Turgut, S.; Bor-Kucukatay, M.; Emmungil, G.; Atsak, P. and Turgut, G. (2007): The effects of low dose Aluminum on hemorheological and hematological parameters in rats. Arch Toxicol, 81(1):11-17.

[12] Harrison, R. M. and Perry, R. (1986): Handbook of air pollution analysis. Chapman and Hall, 2nd ed. London, New York, pp. 149-546.

[13] Brown, B.A. (1993): Haematological principles and procedures. 6th ed. Lippincot, Williams \& Wilking, Philadelphia.

[14] Patton, C.J. and Crouch, S.R. (1977): Spectrophotometeric and kinetics investigation of the Berthelot reaction for determination of ammonia. Anal Chem, 49(3): 464-469.

[15] Henry, R.G. (1974): Clinical chemistry. Chemicals and Technique. $2^{\text {nd }}$ ed. Harper, New York. p.257.

[16] Taylor, D.J; Green, N.P.U. and Stout, G.W. (2003): Biological science. 3rd ed, Cambridge University Press, UK., pp:378.

[17] NIOSH (1992): Recommendations for occupational safety and health: Compendium of policy documents and statements. Cincinnati, OH: U.S. Department of Health and Human Services, Public Health Service, Centers for Disease Control, National Institute for Occupational Safety and Health, DHHS (NIOSH) Publication No. 92-100.

[18] Godderis, L.; Vanderheyden, W.; Van Geel, B. J.; Moens, C. G.; Masscheleina, R. and Veulemansa, H. (2005): Exposure and inhalation risk assessment in an Aluminum cast-house. J Environ Monit, 7(12): 1359-1363

[19] Sakr, C.J.; Taiwo, O.A.; Galusha, D.H.; Slade, M.D.; Fiellin, M.G.; Bayer, F.; Savitz, D.A. and Cullen, M.C. (2010): Reproductive Outcomes Among Male and Female Workers at an Aluminum Smelter. J Occup Environ Med, 52(2): 137-143.

[20] Kondej, D. and Gawęda, E. (2008): Exposure to total and respirable dust of Aluminum and its compounds. Med Pr, 59(5):381 - 386 .

[21] Schwartz, J. (2001): Air pollution and blood markers of cardiovascular risk. Environ Health Perspect, 109 (suppl 3):405-409.

[22] Lei, Y.; Chan, C.; Wang, P.; Lee, C. and Cheng, T. (2004): Effects of Asian dust event particles on inflammation markers in peripheral blood and bronchoalveolar lavage in pulmonary hypertensive rats. Environ Res, 95(1):71-76.

[23] Vittori, D.; Garbossa, G.; Lafourcade, C.; Perez, G.; Nesse, A. (2002): Human 
erythroid cells are affected by Aluminum. Alteration of membrane band 3 protein. Biochimica et Biophysica Acta (BBA)Biomembranes., 1558(2):142-150.

[24] Corain, B. (1992): The solution state of Al (Ш) as relevant to experimental toxicology: Recent data and new perspectives. Coord Chem Rev, 112:1932.

[25] Karmaker, R.; Bhattacharya, R. and Chatterjee, M. (2000): Biochemical, haematological and histopathological study in relation to time-related cadmiuminduced hepatotoxicity in mice. Biometals, 13(3): 231-239.

[26] Naylor, S. (1971): The hematology and histopathology of Trypanosoma congolense infection in cattle. Trop Anim Health Prod, 3(3):159-168.

[27]Orisakwe, O.E.; Nwachukwu, E.; Osadolor, H.B.; Afonne, O.J. and Okocha, C.E. (2008): Liver and kidney function tests amongst paint factory workers in Nkpor, Nigeria. Toxicology and industrial health, 23(3): 161-165.

[28] Katyal, R.; Desigan, B.; Sodhi, C.P. and Ojha, S. (1997): Oral Aluminum administration and oxidative injury. Biol Trace Elem Res, 57(2):125-130.

[29] Berne, M.R. and Levy, N.M. (1998): Physiology. 4th ed. Mosby, New York., pp 910-929.

[30] Shelgikar, P.J.; Deshpande, K.H.; Sardeshmukh, A.S.; Katkam, R.V. and Suryakar, A.N. (2005): Role of oxidants and antioxidants in ARF patients undergoing hemodialysis. Indian $\mathbf{J}$ Nephrol, 15:73-76.

[31] Kowalczyk, E.; Kopff, A.; Kędziora, J.; Błaszczyk, J.; Kopff, M.; Niedworok, J. and Fijałkowski, P. (2004): Effect of longterm Aluminum chloride intoxication on selected biochemical parameters and oxidative-antioxidative balance in experimental animals. Pol J Environ Stud, 13 (1): 41-43.
[32] Pattajoshi, P. K. (2006): Assessment of airborne dust associated with chemical plant: A case study. Indian J Occup Environ Med, 10(1):32-34.

[33]Hałatek, T.; Opalska, B.; Lao, I.; Stetkiewicz, J. and Rydzybnski, K.O. (2005): Pneumotoxicity of dust from Al foundry and pure alumina: a comparative study of morphology and biomarkers in rats. Int J Occup Med Environ Health, 18: 59-70.

[34]Yokohira, M.; Takeuchia, H.; Yamakawaa, K.; Saooa, K.; Matsudaa, Y.; Zenga, Y.; Hosokawaa, K. and Imaidaa, K. (2007): Bioassay by intratracheal instillation for detection of lung toxicity due to fine particles in F344 male rats. Exp Toxicol Pathol, 58(4): 211-221.

[35] Jelinic, J.D.; Mustajbegovic, J.; zuškin, E.; Lukic, J.; Cavar, V. and Ivankovic, A. (2005): Managing occupational safety and health in Aluminum production: case study of Aluminum production factory, Mostar, Bosnia and Herzegovina. Croat Med J, 46(5):838-847.

[36] Jederlinic, P.J.; Abraham, J.L.; Churg, A.; Himmelstein, J.S.; Epler, G.R. and Gaensler, E.A. (1990): Pulmonary fibrosis in $\mathrm{Al}$ oxide workers. Investigation of nine workers, with pathologic examination and microanalysis in three of them. Am Rev Respir Dis, 142(5):1179-1184.

[37] Warheit, D.B.; Yuen, I.S.; Kelly, D.P.; Snajdr, S. and Hartsky, M.A. (1996): Subchronic inhalation of high concentrations of low toxicity, low solubility particulates produces sustained pulmonary inflammation and cellular proliferation. Toxicol Lett, 88(1-3):249253.

[38] Agency for Toxic Substances and Disease Registry (ATSDR) (1990): Toxicological profile for Al. U.S. Department of Health and Human Services. Public Health Service.

[39] Nasiadek, M. and Sapota, A. (2004): Toxic effect of dust and fumes of 
Aluminum and its compounds on workers' respiratory tract. Med $\mathrm{Pr}$, 55:495-500.

[40] NiKula, K. J.; Swafford, D. S.; Hoover, M. D.; Tohulka, M. D. and Finch, G. L. (1997): Chronic Granulomatous Pneumonia and Lymphocytic Responses Induced by Inhaled Beryllium Metal in $\mathrm{A} / \mathrm{J}$ and $\mathrm{C} 3 \mathrm{H} / \mathrm{HeJ}$ Mice. Toxicol Pathol, 25(1): 2-12.

[41] Ohtsukaa, R.; Shutoh, Y.; Fujie, H.; Yamaguchi, S.; Takeda, M.; Harada, T. and Doi, K. (2005): Changes in histology and expression of cytokines and chemokines in the rat lung following exposure to ovalbumin. Exp Toxicol Pathol, 56(6):361-368.

[42]Rabah, S.O.; El Hadad, S.R. and FatmahAlbani, F. (2013): Histological changes of Mice lungs after daily exposure to different concentration of Incense smoke. Life Sci J, 10(1):552-560.

[43]Alarifi, A. (2005): Morphological evidence of apoptosis in hepatocytes of rats (Rattusnorvegicus) exposed to Arabian incense. J Med Sci, 5(3): 222227.
[44] Dai, J.; Gilks, B.; Price, K. and Churg, A. (1998): Mineral dusts directly induce epithelial and interstitial fibrogenic mediators and matrix components in the airway wall. Am J Respir Crit Care Med, 158(6):1907-1913.

[45]Wang, C.Z.; Li, A. and Yang, Z.C. (1990): The pathophysiology of carbon monoxide poisoning and acute respiratory failure in a sheep model with smoke inhalation injury. Chest, 97(3):736-742.

[46] Rabah, S.O and El Hadad, S.R. (2012): Ultrastructural changes occur in mice lungs after cessation to exposure of incense smoke. Life Sci J, 9(2): 959-969.

[47] Davarian, A.; Fazeli, S. A.; Azarhoush, R. and Golalipour, M. J. (2005): Histopathologic changes of rat tracheal mucosa following formaldehyde exposure. Int J Morphol, 23(4):369-372.

[48] Schlesinger, R. B.; Snyder, C. A.; Chen, L. C.; Gorczynski, J. E. and Menache, M. (2000): Clearance and translocation of Aluminum oxide (alumina) from the lungs. Inhal Toxicol, 12(10): 927-939. 


\section{الملخص العربي}

التغيرات الاموية و الكيميائية الحيوية والنسيجية أثر التعرض لأتربة الألومنيوم

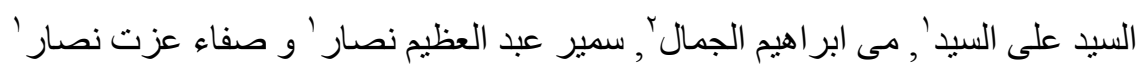

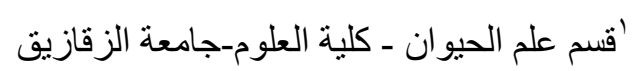

"قسم علوم البيئة ـ كلية العلوم-جامعة دمياط

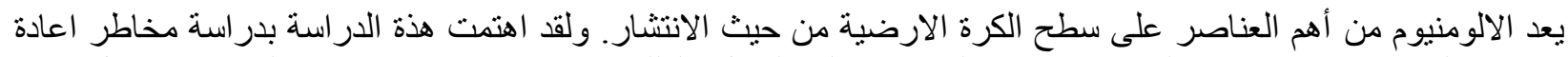

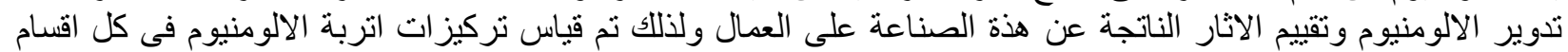

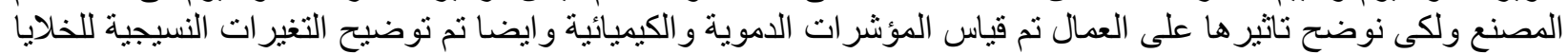

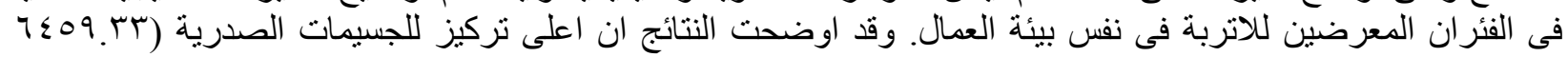

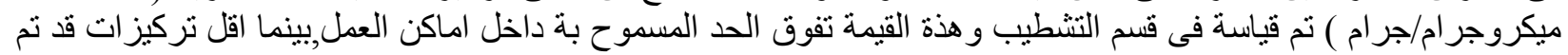

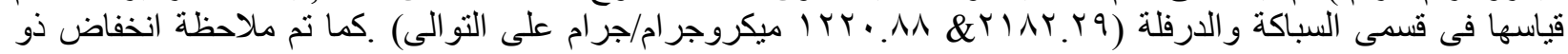

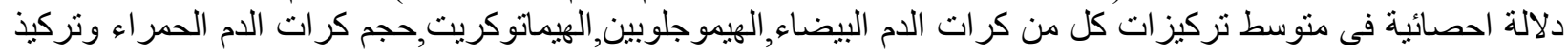

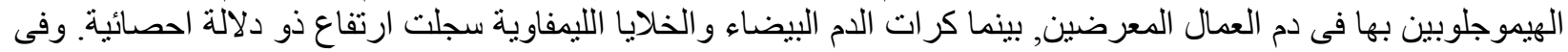

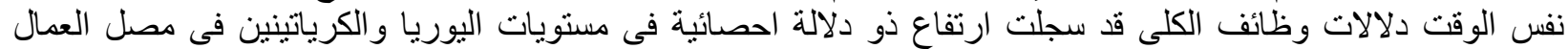

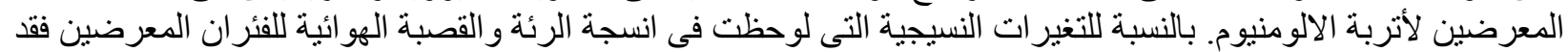

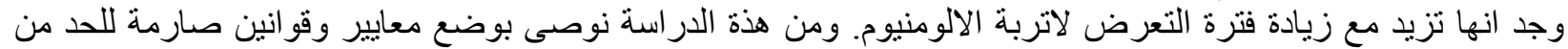

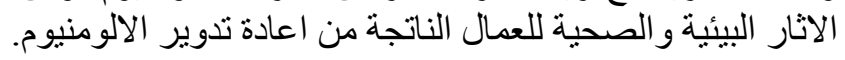

